\title{
Land application of farm dairy effluent for sustainable dairy farming
}

\author{
C.G. ROACH ${ }^{1}$, R.D. LONGHURST ${ }^{2}$ and S.F. LEDGARD ${ }^{2}$ \\ ${ }^{1}$ WestpacTrust Agricultural Research Station, R.D. 12, Hawera \\ ${ }^{2}$ AgResearch, Ruakura Research Centre, PB 3123, Hamilton \\ dexcel.taranaki@netsource.co.nz
}

\begin{abstract}
Land application of farm dairy effluent (FDE) is preferred over pond treatment because of the potential reduction in environmental impacts, and recycling of valuable nutrients. Recent findings from the past 5 years of research by AgResearch and Dexcel are presented to provide an overview of the effects of applying FDE to pastures. Results indicate that significant pasture responses to applying FDE at increasing rates of $\mathrm{N}$ were found in both the mowing and grazing trials. There was no difference in pasture responses between FDE and urea when applied at the same rate of $\mathrm{N}$. The ryegrass content of pastures increased with increasing $\mathrm{N}$ rates whether from effluent or urea. $\mathrm{N}$ and nitrate- $\mathrm{N}$ concentrations in the herbage showed some increases but were not excessive at rates up to $400 \mathrm{kgN} / \mathrm{ha} / \mathrm{yr}$. Pasture concentrations of other nutrients (except K) were unaffected by the rate or form of nitrogen applied. Both pasture $\mathrm{K}$ and soil $\mathrm{K}$ levels were significantly higher under the effluent treatments. Nitrate and calcium leaching increased significantly under the highest rate of $\mathrm{N}$ application (400 kgN/ha/yr). Spreading FDE over a sufficiently large area (15-20\% of the farm) can reduce inputs of $K$ to near maintenance requirements and restrict $\mathrm{N}$ inputs to about 80 $120 \mathrm{~kg} \mathrm{~N} / \mathrm{ha} / \mathrm{yr}$, thereby avoiding potential animal health and environmental problems.

A behavioural study showed that cows disliked grazing pastures recently treated with FDE. This study also showed that there was a significant and rapid decline in faecal coliform counts on pasture following effluent application.
\end{abstract}

Keywords: faecal coliforms, farm dairy effluent, FDE, groundwater, nitrate leaching, pasture, soil

\section{Introduction}

Approximately half of the dairy herds in New Zealand are in the Waikato and Taranaki regions. From the mid-1990s, Regional Councils have encouraged landbased effluent application systems on dairy farms as the means of decreasing point-sources of agricultural pollution of waterways. Farmers are being required to use land application of farm dairy effluent (FDE) as the preferred option, either directly from the dairy shed or indirectly from holding ponds. Regional Councils have recommended rates for land application of FDE at $150-200 \mathrm{~kg} \mathrm{~N} / \mathrm{ha} /$ year. Except for a 4-year study in Northland during the 1970s (Goold 1980), little field research has been conducted on the effects of applying FDE to pastures at sustainable rates. This paper draws together the knowledge from field trials conducted by AgResearch and Dexcel (formerly DRC) over the past 5 years that have looked at various aspects of applying FDE to pastures.

\section{Methods and materials}

Waikato mowing trial: A field trial was conducted by AgResearch on a volcanic ash soil at the No. 1 Dairy, Ruakura, Hamilton, where fresh FDE was applied (over 17 applications) at six rates of $\mathrm{N}(0,75,150,225,300$, $375 \mathrm{~kg} / \mathrm{ha}$ ) with four replicates. Measurements taken over 18 months included pasture production (by cutting with $60 \%$ clipping removal), total nitrogen and nitrate$\mathrm{N}$ pasture concentrations, botanical composition, and nitrate- $\mathrm{N}$ and ammonium-N in soil solution (using zerotension lysimeters at $1 \mathrm{~m}$ depth), as described in Longhurst et al. (1999). Water was applied so that each plot received the same volume of liquid, to balance any irrigation effect of FDE application.

Taranaki grazing trial: At the WestpacTrust Agricultural Research Station (WTARS), near Hawera in South Taranaki, urea fertiliser (U) or pond-stored FDE was applied to paddocks (three replicates) at rates of: 0 (Control), 100,200 , or $400 \mathrm{kgN} / \mathrm{ha} / \mathrm{yr}$. The FDE and urea was applied monthly from September to April of each year, at rates of $0-50 \mathrm{kgN} / \mathrm{ha}$, with the FDE nitrogen content analysed prior to application to ensure similar $\mathrm{N}$ application rates. Measurements were made of nitrate leaching (using ceramic cup samplers at $1 \mathrm{~m}$ depth in conjunction with lysimeters) and groundwater quality, pasture production (using calibrated visual assessment), pasture composition and feed quality, and soil fertility. Maintenance fertiliser was applied to all paddocks, supplying $\mathrm{P}, \mathrm{K}$, and $\mathrm{S}$ at 45,60 , and $60 \mathrm{~kg} / \mathrm{ha} / \mathrm{yr}$ respectively. Data for the first 
year of this trial were presented by Roach et al. (2000). This paper summarises results for 3 years.

Waikato behavioural study: A short-term trial was conducted at the Ruakura No. 5 dairy, where cow preference for grazing effluent-treated pastures was observed. Fresh FDE was applied at 5-day intervals (5, $10,15,20,25$ days) prior to grazing and compared with untreated pasture. Each cow was placed in a strip that contained an untreated plot and plots treated 5, 10, 15,20 , and 25 days prior to grazing. Pasture consumption, cow behaviour and faecal bacteria decline on treated and untreated pasture were measured (Longhurst et al. 2000a).

\section{Results and discussion}

\section{Type of effluent}

While the Waikato trials used fresh FDE (fFDE), the effluent used in the Taranaki trial (pFDE) was liquid collected from the anaerobic oxidation pond, which in effect became a storage pond as outflow to the aerobic pond no longer occurred. The pond liquid (pFDE) contained lower concentrations of nutrients (Table 1), and a larger proportion of the $\mathrm{N}$ was readily available. Both fFDE and pFDE contained significant amounts of potassium.

Table 1 Comparison of nutrient content (mg/L) of fresh effluent (from Longhurst et al. 2000b) and pond liquid effluent (from Taranaki trial).

\begin{tabular}{lccccc}
\hline & N & P & K & S & \% N readily available \\
\hline Fresh & 400 & 70 & 370 & 65 & 19 \\
Pond liquid & 214 & 26 & 242 & 8 & 67 \\
\hline
\end{tabular}

\section{Effect on pasture growth}

Pasture production responses in the Waikato mowing trial showed that DM yields increased significantly $(\mathrm{P}<0.001)$ with increased rates of fFDE (Table 2). Another finding was that the pasture responses to fFDE had both immediate and long-lasting (up to a year after application) effects. This was probably owing to the forms of $\mathrm{N}$ present in fFDE with about $80 \%$ present as slower-release organic-N (Longhurst et al. 2000b).

In Taranaki, annual pasture production showed similar responses to increased rates of $\mathrm{pFDE}$, but there was no difference between $\mathrm{pFDE}$ and urea when applied at the same rate of N. It should be noted that, partly owing to the number of replicates (three), differences were often not significant.

These results demonstrate that FDE can produce extra pasture growth equivalent to that obtained from using fertiliser $\mathrm{N}$.
Table 2 Pasture dry matter responses to FDE (relative to control) in Waikato (18 months) and Taranaki (mean of 3 years).

\begin{tabular}{|c|c|c|c|c|}
\hline \multicolumn{2}{|c|}{---------- Waikato ---------- } & \multicolumn{3}{|c|}{------------- Taranaki ------------- } \\
\hline Kg N/ha applied & fFDE & $\begin{array}{l}\mathrm{Kg} \mathrm{N} / \mathrm{ha} / \mathrm{yr} \\
\text { applied }\end{array}$ & pFDE & Urea \\
\hline 0 (control) & 100 & 0 (control) & 100 & 100 \\
\hline 75 & 107 & & & \\
\hline & & 100 & 102 & 105 \\
\hline 150 & 115 & & & \\
\hline & & 200 & 117 & 114 \\
\hline 225 & 115 & & & \\
\hline 300 & 121 & & & \\
\hline 375 & 124 & & & \\
\hline & & 400 & 109 & 116 \\
\hline SEM & 3 & & 12 & \\
\hline
\end{tabular}

\section{Effect on botanical composition}

The Waikato mowing trial began with a grass dominant sward $(87 \%)$ and this continued throughout the trial with no significant differences in composition measured. Similarly, in a Northland grazing trial, Goold (1980) found little effect on grass and legume content from 4 years of effluent application. In the Taranaki grazing trial, ryegrass content of pastures increased $(\mathrm{P}<0.05)$ with increased nitrogen application rates. The content of clover and other grasses tended to decrease with increased $\mathrm{N}$ application. Increasing pFDE application rates may also reduce clover nitrogen fixation, as measured in studies with $\mathrm{N}$ fertiliser (e.g., Ledgard et al. 1999). Clover content tended to be greater under pFDE application than urea at the same $\mathrm{N}$ rate, though differences were not always significant (Figure 1).

Figure 1 Clover content of pastures (\% DM) in the Taranaki trial (average of 3 years' data). The pFDE and urea data are the average of all rates. Vertical error bar is average SED.

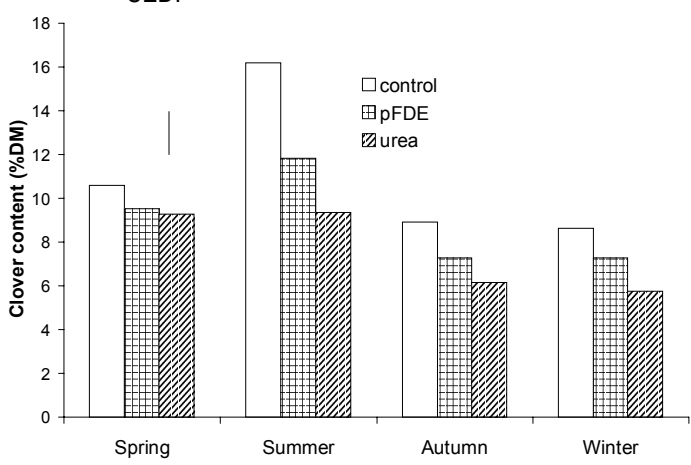

Effect on chemical composition and feed value of pasture

Pasture $\mathrm{N}$ concentrations in the Waikato mowing trial averaged $2.9 \%$ in the control treatment and at no stage during the trial did concentrations exceed $4.5 \%$ for any 
treatment. Nitrate-N concentrations averaged $0.013 \%$ for the control treatment and increased to $0.035 \%$ at the highest rate $(375 \mathrm{~kg} \mathrm{~N} / \mathrm{ha})$, well below the $0.20 \%$ maximum level considered safe for feeding (Ellison \& Feyter 1988).

In the Taranaki grazing trial, rates or form of nitrogen did not affect the protein, lipid, fibre, energy content, digestibility, nitrogen, phosphorus, or sulphur concentrations of the pasture grown (data not presented). However, in winter and spring, potassium (K) concentrations in pasture (Figure 2) and soil (Figure 3) were consistently higher under effluent than the control or urea treatments. The increased $\mathrm{K}$ levels were largely owing to the high $\mathrm{K}$ inputs from $\mathrm{pFDE}$, with $\mathrm{N}$ and $\mathrm{K}$ concentrations (and annual application rates) in the pFDE applied in this trial being similar. There was no indication of an effect on $\mathrm{Ca}$ and $\mathrm{Mg}$ concentrations in the pasture. In contrast, a Massey study with a single large application of FDE at 150 $\mathrm{kg} \mathrm{N} / \mathrm{ha}$ showed increased $\mathrm{K}$ and decreased $\mathrm{Ca}$ and $\mathrm{Mg}$ concentrations (Bolan 2001). The increase in pasture $\mathrm{K}$ levels has important implications for animal health, since it can reduce $\mathrm{Ca}$ and $\mathrm{Mg}$ absorption in dairy cows and increase susceptibility to milk fever and grass staggers (Grace 1983). From survey data of FDE on farms (Vanderholm 1984; Longhurst et al. $2000 \mathrm{~b}$ ), the average concentration of $\mathrm{K}$ was about $80 \%$ of the $\mathrm{N}$ concentration. Use of moderate rates of FDE over a sufficiently large area (e.g., c. $100 \mathrm{~kg} \mathrm{~N} /$ $\mathrm{ha} / \mathrm{yr}$ and $80 \mathrm{~kg} \mathrm{~K} / \mathrm{ha} / \mathrm{yr}$, equivalent to c. $18 \%$ of the farm area), with split applications through the year, mean that FDE can substitute for maintenance $\mathrm{K}$ fertiliser (e.g., $50-90 \mathrm{~kg} \mathrm{~K} / \mathrm{ha} / \mathrm{yr}$ for farms on ash soils producing $800-1200 \mathrm{~kg}$ milksolids/ha) and minimise potential cow metabolic problems.

Figure 2 Pasture potassium concentrations (\% DM) in the Taranaki trial. The urea data refer to the average of all rates, which showed no significant difference. Vertical error bar is average SED.

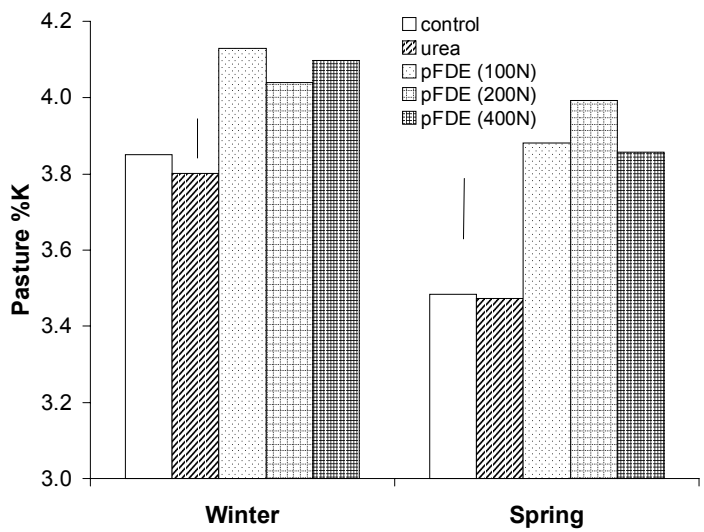

Figure 3 Soil Quicktest potassium status $(0-7.5 \mathrm{~cm})$ in the Taranaki trial. Data for pFDE and urea are the average of all $\mathrm{N}$ rates.

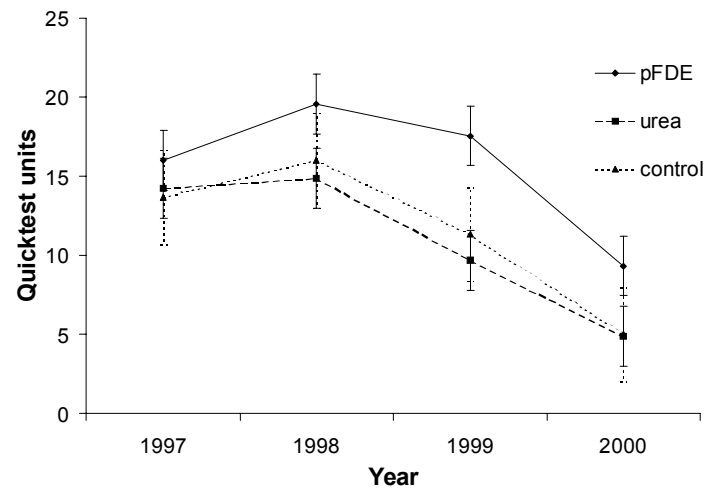

Early results from a grazing preference trial in Taranaki also suggests that dairy cows avoid grazing high potassium pastures (Jeff Morton, pers. comm.).

\section{Effect on nitrate leaching losses}

Nitrate-N concentrations (Figure 4a) and total nitrate$\mathrm{N}$ leaching losses (Figure $4 \mathrm{~b}$ ) in the Taranaki study showed no significant difference between the control, 100 and 200 rates, but increased markedly in the $400 \mathrm{~N}$ treatments $(\mathrm{P}<0.05)$, where average nitrate- $\mathrm{N}$ concentrations in the drainage water were approximately double the recommended maximum for drinking water. Nitrate leaching losses were similar to that measured by Ledgard et al. (1999) in a long-term Waikato dairy farmlet study. As well as nitrate- $\mathrm{N}$, calcium leaching also increased significantly (by up to $44 \mathrm{~kg} \mathrm{Ca} / \mathrm{ha} / \mathrm{yr}$ ) under the higher rates of application (data not presented). These results support the recommendations of regional councils in limiting application rates to $150-200 \mathrm{~kg} \mathrm{~N} / \mathrm{ha} /$ year, while also indicating that moderate application rates will have little to no adverse effect on nitrate concentrations in drainage to groundwater.

\section{Effect of faecal contamination}

Pasture measurements in the Waikato grazing trial detected significant differences $(\mathrm{P}<0.001)$ in the amount of pasture consumed from plots and the length of time since effluent applications (Table 3). The same trend was observed for number of bites and length of time spent on plots, indicating a clear dislike for the most recently treated pasture (Table 3 ).

Faecal coliform concentrations in the fFDE applied to the pasture averaged $9.1 \times 10^{5}$ MPN (most probable numbers). MPN were significantly higher on the most recently treated pasture but after 10 or more days, faecal coliform concentrations were not different from 
the control pasture (Table 3 ). The rapid die-off suggests that the faecal coliforms had been inactivated, or washed off by rain, as observed by Hubbell et al. (1973). However, other pathogenic bacteria may be present and can survive longer in the environment than the indicator (faecal coliform) bacteria that are always present in faeces (Donnison 2001).

Therefore, until further long-term studies are undertaken it would be advisable for farmers to withhold grazing cattle from effluent-treated pasture for a minimum of 15 days, and preferably 20 days if possible. A 20-day period allows time for further bacterial inactivation and farmers should find that cattle will then graze effluent-treated pastures as readily as untreated pasture.

\section{Conclusions}

Farm dairy effluents are liquid by-products rich in $\mathrm{N}$ and K. Pasture responses as good as those from fertiliser $\mathrm{N}$ have been achieved when FDE has been applied to pasture. These pasture responses can last for at least 1 year. Except for potassium, the nutrient status of pastures was not significantly different from the non-effluent pastures. Both pasture and soil potassium levels can be significantly higher under effluent treatments as the amount of $\mathrm{K}$ applied in FDE exceeds pasture maintenance requirements at rates above about $100 \mathrm{~kg} \mathrm{~N} / \mathrm{ha} / \mathrm{year}$, and this can increase the potential for metabolic problems in livestock. FDE application rates should be limited by K concentration, rather than the $\mathrm{N}$, on farms with high pasture $\mathrm{K}$ levels or where milk fever and grass staggers are a problem. Nitrate leaching increases significantly when pond FDE is applied at rates above $200 \mathrm{~kg} \mathrm{~N} / \mathrm{ha} / \mathrm{yr}$. Limiting FDE applications to c. $100 \mathrm{~kg} \mathrm{~N} / \mathrm{ha} / \mathrm{yr}$ would mean that more of the farm could be covered, approximate pasture maintenance inputs for potassium would be supplied, and nitrate leaching would be minimised. Dairy cows should be withheld from grazing pastures treated with fresh FDE for at least 15 days, and preferably 20 days, to enhance intake and minimise animal health risks.
Figure 4 (a) Nitrate- $\mathrm{N}$ concentration in drainage water relative to recommended maximum for drinking water (dotted line) and (b) nitrate- $\mathrm{N}$ leaching losses. Results are average of 3 years' data. Vertical bars are average SED.
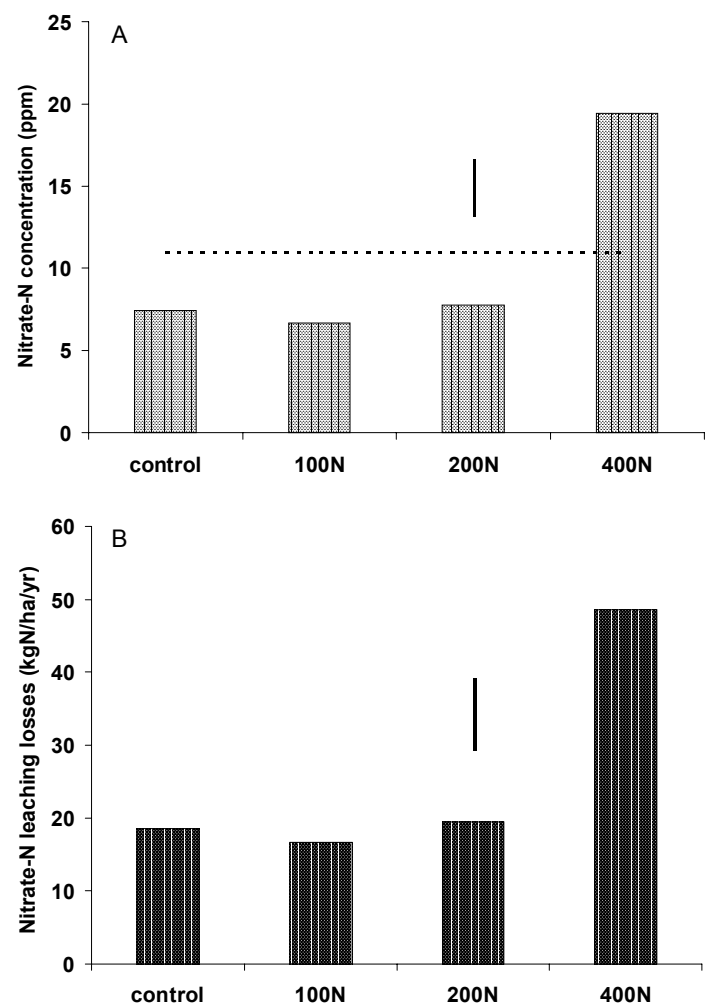

Table 3 Pasture and cow behaviour measurements when grazing effluent treated pastures for the six treatments, plus faecal coliform counts on pasture in the Waikato cow behavioural study.

\begin{tabular}{|c|c|c|c|c|c|c|c|}
\hline Observations & Days & ince & ffluen & appli & cation & & \\
\hline & 5 & 10 & 15 & 20 & 25 & Control & SED \\
\hline Cumulative rainfall $(\mathrm{mm})$ & 1 & 30 & 38 & 51 & 61 & - & \\
\hline $\begin{array}{l}\text { Pasture } \\
\% \text { consumed }\end{array}$ & 7 & 12 & 21 & 26 & 24 & 31 & 5 \\
\hline $\begin{array}{l}\text { Cow Behaviour } \\
\text { Time on plots (sec) } \\
\text { Bites (number) }\end{array}$ & $\begin{array}{l}79 \\
10\end{array}$ & $\begin{array}{r}190 \\
54\end{array}$ & $\begin{array}{r}169 \\
90\end{array}$ & $\begin{array}{l}240 \\
123\end{array}$ & $\begin{array}{l}243 \\
105\end{array}$ & $\begin{array}{l}264 \\
175\end{array}$ & $\begin{array}{l}49 \\
28\end{array}$ \\
\hline $\begin{array}{l}\text { Faecal coliforms } \\
\text { MPN (gm/wet wt.) }\end{array}$ & 148 & 5 & 4 & 2 & 2 & $<1$ & $22^{*}$ \\
\hline
\end{tabular}

\section{ACKNOWLEDGEMENTS}

Taranaki Regional Council, Ministry for the Environment, and Foundation for Research, Science and Technology for funding these research projects. Technical staff at the WestpacTrust Agricultural Research Station, Hawera and AgResearch Ruakura for assistance in conducting the trials.

\section{REFERENCES}

Bolan, N.S. 2001. Nutrient recycling from farm effluent. Water and Wastes in New Zealand 117: 32-35.

Donnison, A. 2001. Land disposal of effluent: a brief review of some faecal microbial issues. pp.9-16. 
In: New Zealand Land Treatment Collective: Proceedings for the 2001 Annual Conference, Invercargill.

Ellison, R.S.; Feyter, C. 1988. Optigrow animal health profiles - a guide for veterinarians. MAF, Hamilton.

Goold, G.J. 1980. Rates of dairy shed effluent applied to pastures on clay soils in Northland. New Zealand Journal of Experimental Agriculture 8: 93-99.

Grace, N.D. 1983. The mineral requirements of grazing ruminants. New Zealand Society of Animal Production Occasional Publication 9.

Hubbell, D.; Smith, P.; Dazzo, F. 1973. The influence of manure slurry irrigation on the survival of faecal organisms in Scranton fine sand. Journal of Environmental Quality 2: 29-36.

Ledgard, S.F.; Penno, J.W.; Sprosen, M.S. 1999. Nitrogen inputs and losses from clover/grass pastures grazed by dairy cows, as affected by nitrogen fertilizer application. Journal of Agricultural Science, Cambridge 132: 215-225.

Longhurst, R.D.; O'Connor; M.B., Roberts, A.H.C.; Waller, J.E. 1999. Farm dairy effluent: Findings of recent research studies in the Waikato. pp. 273282. In: Best Soil Management Practices for
Production. Eds. Currie L.D.; Hedley, M.J.; Horne, D.J.; Loganathan, P. Occasional Report No. 12, Fertilizer and Lime Research Centre, Massey University, Palmerston North, New Zealand.

Longhurst, R.D.; O'Connor, M.B.; Bremner, K.; Mathews, L. 2000a. Animal constraints to pasture treated with farm dairy effluent: Preference under grazing and issues of faecal contamination. New Zealand Journal of Agricultural Research 43: 501507.

Longhurst, R.D.; Roberts, A.H.C.; O’Connor, M.B. 2000b. Farm dairy effluent: review of published data on chemical and physical characteristics in New Zealand. New Zealand Journal of Agricultural Research 43: 7-14.

Roach, C.G.; Stevens, G.; Clark, D.A.; Nicholas, P. 2000. Effects of effluent and urea application on groundwater, soil and pastures at WTARS. Proceedings of the New Zealand Grassland Association 62: 173-178.

Vanderholm, D.H. 1984. Agricultural waste manual. NZAEI Project Report No. 32. New Zealand Agricultural Engineering Institute, Lincoln College, Canterbury. 